Water and Society V 55

\title{
DECISION SUPPORT SYSTEMS FOR WATER RESOURCE MANAGEMENT APPLIED TO ANDEAN SUPPLY MICRO-BASINS
}

\author{
CARLOS MATOVELLE \\ Laboratorio de Contaminación Ambiental y Manejo de Agua, Universidad Católica de Cuenca, Ecuador
}

\begin{abstract}
Different aspects affect the availability of water, among them the dispersion of human settlements, the mismanagement of water sources, and the lack of implementation of plans, programs, and projects in watersheds. The Tabacay river micro basin is of great importance because it is the only water source that supplies the city of Azogues and rural populations. However, no tools have been developed for the planning and management of the resource. A Decision Support System is proposed through the hydrological simulation of the contributions of the basin and the application of urban supply criteria to identify the problem of the study area. Among the results obtained, it is observed that currently in the Tabacay river basin the guarantee of irrigation demand complies with the UTAH-Division of Wildlife Resources (DWR) criterion for the next 30 years, while guaranteeing demand for human consumption in a short-term scenario. it is not fulfilled, with the population increase problems appear for the urban supply. Finally, some non-structural and structural measures are proposed which, through the simulation of scenarios, can reduce the water deficit in the micro-basin.
\end{abstract}

Keywords: Decision Support System (DSS), Andean micro-basin, demands, failure, guarantee.

\section{INTRODUCTION}

Water is a resource that is related to numerous human activities and the environment in which they develop [1]. The advance of economic activities and the change of land use due to inadequate territorial planning have favored the soils of watersheds to be affected and degraded, causing a direct effect on the quality of water resources due to diffuse pollution from lands, primarily agricultural and livestock. In addition to that, there may be direct pollution by urban wastewater discharges without treatment and industrial activities.

The water resources management includes two components that must be integrated, the first is the management of the sources of the resource, and the second is that the demands that exist must be met [2]. To preserve the resource, both qualitatively and quantitatively, it is necessary to include a hydrological and water resources planning in a watershed that allows adequate management and conservation of water [3]. To improve the planning of the resource have developed several methods that have a scientific basis of great importance and the cohesion of all these methodologies allow the development of a Decision Support System (DSS).

There are watersheds in which water planning has not been emphasized and which have neglected the two fundamental components of analysis, that is to say; these systems do not know their recourse potential, and therefore they find themselves in a situation in which satisfying the demand is left to the fortune. For this purpose, the decision support system AQUATOOL and its SIMGES module have been used, which can be approached to the management of the basin in a precise manner. The contribution of the DSS to the management of an area with great interest in its charge for the provision of a city was analyzed, and management alternatives were proposed to mitigate this water problem, in this study aims to evaluate the optimal management options so that there are no failures in the endowment towards the city and that the simulations performed are a contribution to decision-making in 
the management of the resource. After executing a hydrological model of contributions of the river basin that has an optimal adjustment with the series of observed data, the simulations of scenarios can be carried out depending on the problems that are analyzed in the study area. Raising situations with simulations allows optimizing economic, technical, and human resources, giving managers the possibility to make the right decisions.

\section{STUDY AREA}

The study area is located in the south of Ecuador, in the city of Azogues (Fig. 1). It is a micro basin that has typical characteristics of high-altitude areas, in which the rivers have high turbulence, low flows, high slopes and water temperatures around $12^{\circ} \mathrm{C}$ in its source in the upper zone of Páramo.

The micro basin of the Tabacay River, with an approximate area of $65 \mathrm{~km}^{2}$, presents an Andean area climatology in which the average annual temperature is approximately $15^{\circ} \mathrm{C}$, rainfall around $1100 \mathrm{~mm} /$ year and according to Ochoa-Sánchez et al. [4] the evapotranspiration realities in basins close mark values of $620 \mathrm{~mm}$ per year. The analyzed area is of great importance for the city since by the geographical location it is the only source of direct supply for population endowment and irrigation.

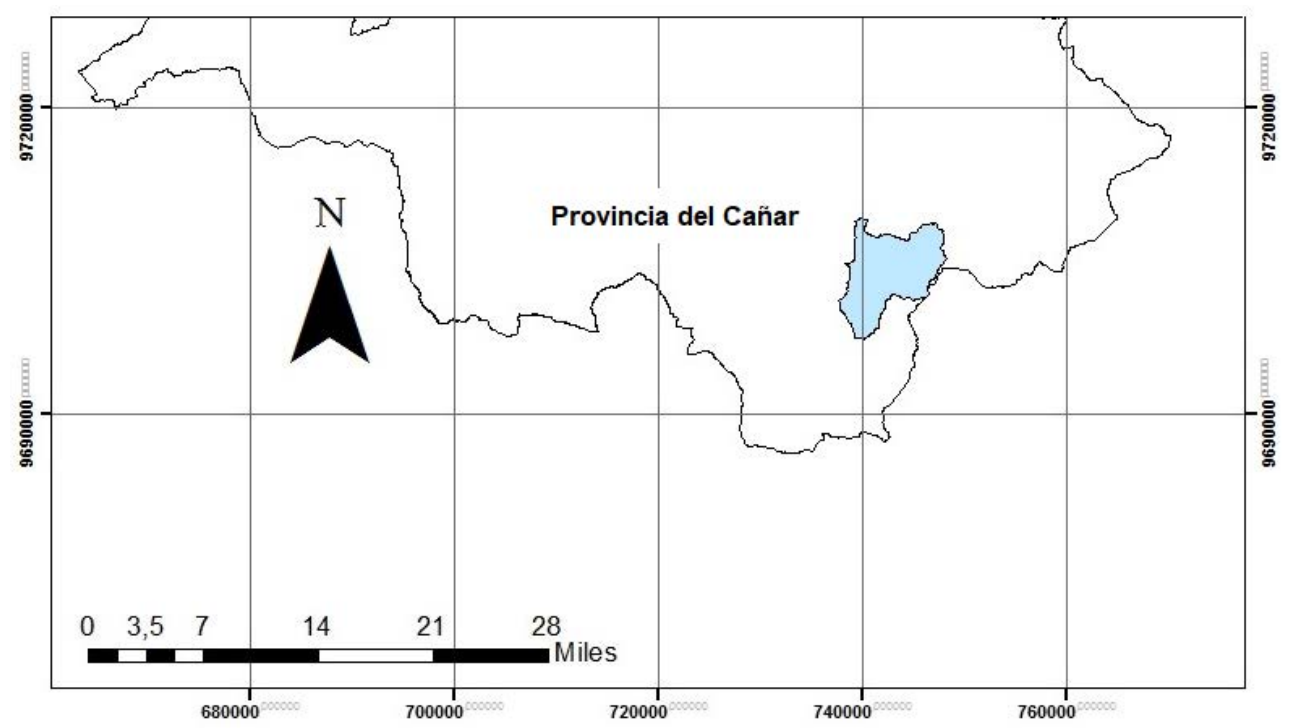

Figure 1: Location of the studied area.

The Tabacay River micro basin is formed by five main rivers Mapayacu, Condoryacu, Rosario, Nudpud and Llaucay in which water is collected for the population, in addition to the confluence between Condoryacu and Rosario, a direct intake is made for irrigation. The water catchment of the main rivers supplies the city of Azogues with an urban beneficiary population of 37150 inhabitants and the direct intake of irrigation is taken to an area of around $45 \mathrm{~km}^{2}$. The amount of land dedicated to agriculture is high, and it is not planned satisfactorily, so the problems of water resources increase. The change in land use has produced an increase in the pollutants that reach the bodies of water, and therefore, the potential it has for provision decreases (Fig. 2). 


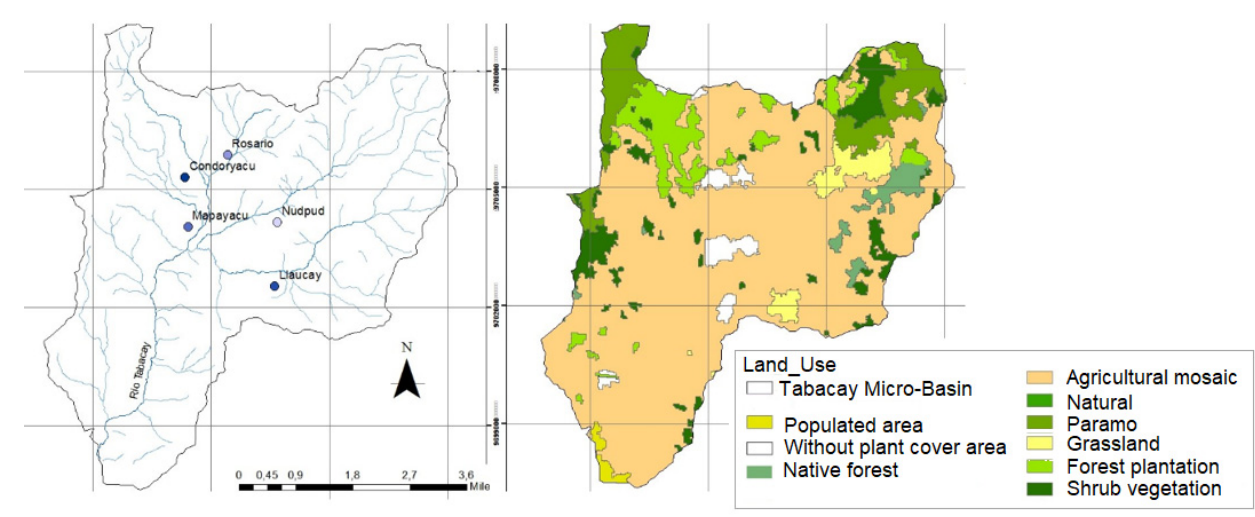

(a)

(b)

Figure 2: (a) Captures of the basin for water supply; (b) Uses of soil.

\subsection{Water resources problems of the Tabacay River micro basin}

The Tabacay River basin presents some specific characteristics that affect the management and exploitation of the water resources:

1. The activities of human origin such as, agriculture, livestock and urban planning affect the quality of water [5], There are specific discharges and diffuse pollution in many stretches of the analyzed river, this directly affects availability for human resources.

2. The Paramo reflects its importance in the ability to store water in its soil and then feed rivers and streams [6]. The intervention in this area puts at risk the conservation of protected areas, water regulation and sources of drinking water supply for the city of Azogues.

3. Another of the significant problems in this basin is the lack of information on the behavior of the flows that it contributes, we work with data collected and measured monthly in each one of the captures, but it leaves a high uncertainty of the real behavior. By not having regulation, the available resource cannot be used in its entirety.

4. There is no regulation system, so the problems of resource allocation become more complicated, difficult to analyze and solve.

\section{METHODS}

The management model is constructed in which the different elements of the analyzed system are introduced: the demands and their returns, the water inlets through the run-off and the river sections [7], to be analyzed in different scenarios of exploitation of the resource. Water resources systems analysis comprises all the necessary elements to describe a river basin [8]. In this way, a water resources model can be proposed that allows decision makers to choose possible alternatives; proper planning is the best way to meet goals set in water management.

\subsection{Data collection}

For the analysis of the water resource management in the Tabacay river basin, the data from meteorological stations located in the study territory are analyzed, it is analyzed for a period 
between 2010 and 2016 since it is the information available. To precipitations and temperature with which the evapotranspiration of the system is determined. For the flow data, the water intake measurements were determined to the catchments that are then taken to the supply. We work with two demands in the model, the first is the demand for drinking water supply for the Azogues city, and the second is the demand that has the channels for irrigation of the cultivated area. With the endowment, there is no problem since there are measured data, but the allocation given to flooding is difficult to quantify since there are several water withdrawals along the rivers that are not registered. In situ work, all existing irrigation water intakes have been measured, and their value has been quantified, the average values of the measured values have been worked on and are presented in Fig. 3.

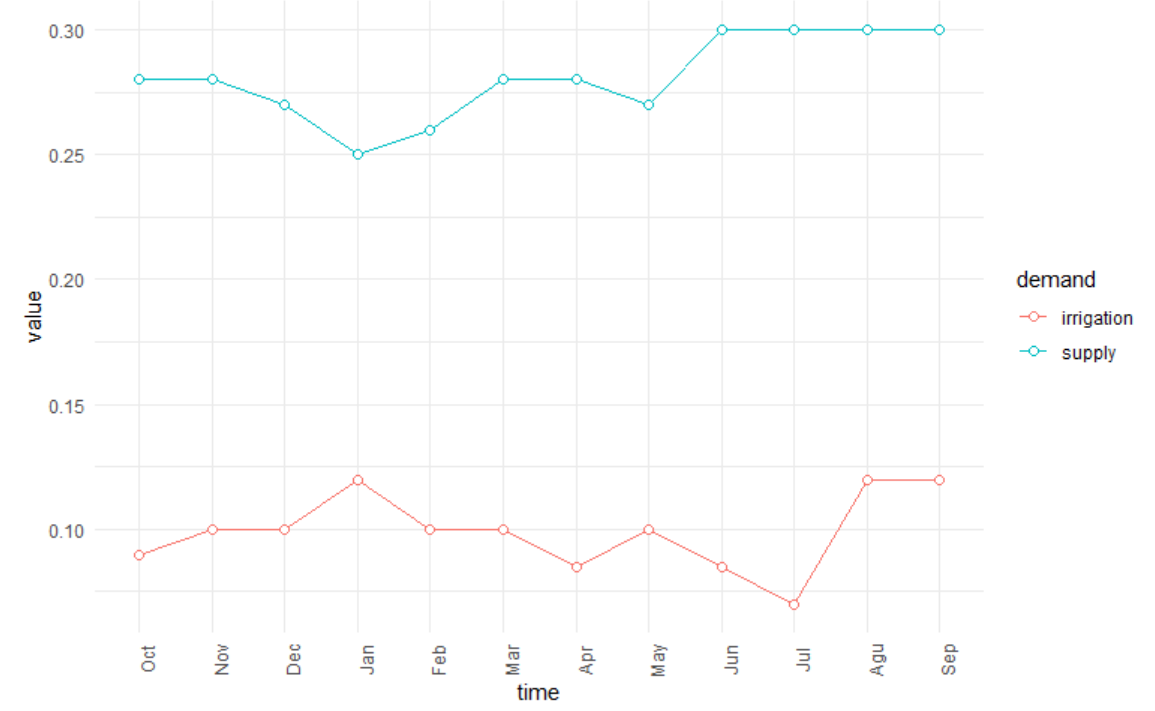

Figure 3: Comparison of the demands in the area of analysis.

\subsection{Model development}

The simulation is carried out using a mass balance, expressed in eqn (1)

$$
V_{f}=V_{i}+A_{e}+A_{i}-P_{f}-E-S_{c}-S_{v} \text {. }
$$

This equation is commonly used to determine the volume of water at the end of a period, considering the amounts of water at the beginning of the analysis and the contributions and losses that exist in the system.

To correctly manage the resources, first, we must know the current situation of the micro-basin with its tributaries, to simulate this we work with AQUATOOL and particularly with the SIMGES modules, which is a generic DSS developed at the University of Valencia, Spain. It was originally designed for the planning stage of decision-making associated with complex river basins. Its base focuses on classic system analysis methodology, but the software has been incorporating the new requirements that mark current needs through the modules [9]. Since this study proposes the adequate management of water, the use of the SIMGES module allows an analysis sufficient to know the state of the system, to make 
scenarios and to propose suitable alternatives. Fig. 4, shows the general scheme of the Tabacay river basin, made from the components proposed by AQUATOOL; this is the base point of the simulations and analysis to offer other scenarios.

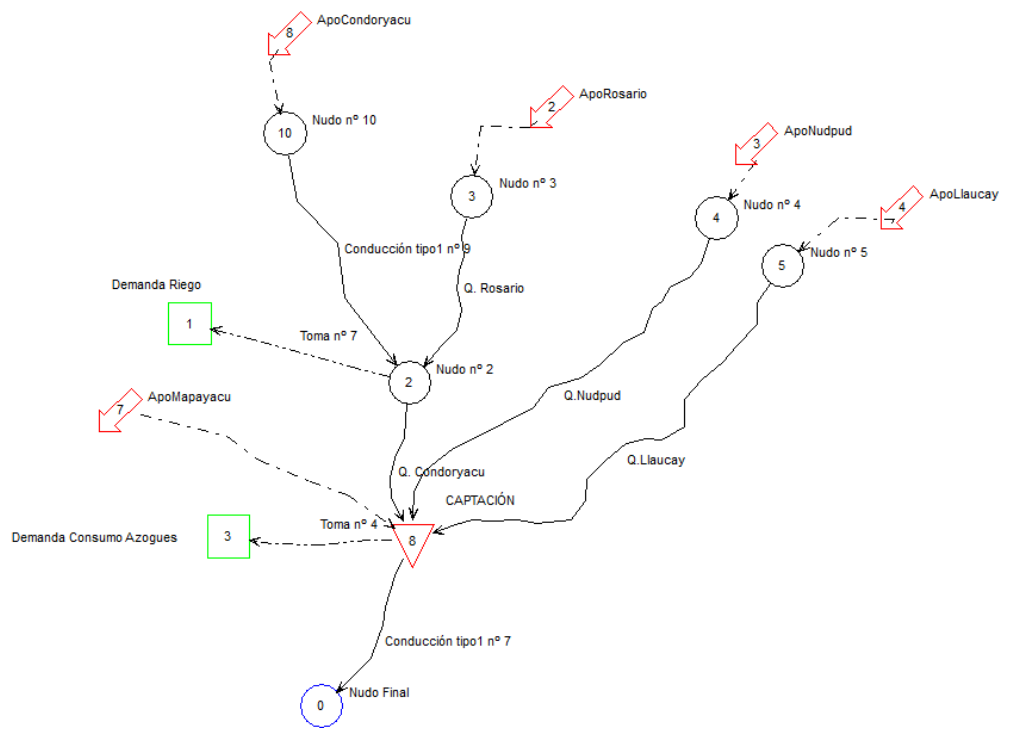

Figure 4: Outline of the Tabacay river micro-basin.

In the scheme the demands analyzed for the system are observed, the irrigation demand is the grouping of the measurement of the data in all the water abstraction for this purpose. Two simulations of scenarios are carried out: current and future. Calibration for the simulation of the current situation is the basis for setting the future scene in which the demands grow, and the system is regulated with a virtual reservoir. In case of a breach in the satisfaction of the demands as proposed [10], the implementation of a reservoir with an ideal capacity for total satisfaction of the demands is planned; However, this perfect capacity means that there will be no physical, economic, social and environmental restrictions in the construction of the infrastructure. The reservoir that is observed in the figure is only for the capture of water in the current scenario and will serve to simulate the future situation with the virtual regulation.

\section{RESULTS}

The results of the two proposed simulations are presented and analyzed, although the second is divided into two alternatives, the first is analyzed with the introduction of future demand and the information of the series of historical monthly contributions, assuming that the natural regime The flow of the sub-basin will not change with time and later, the entrance of a reservoir with ideal characteristics is planned so that there are no faults in the water supplies.

\subsection{Simulation of water resources systems using SIMGES}

The adjustment of the model in the current scenario is developed as proposed by Paredes et al. [11] where the oldest data is used for the validation and the most recent for the calibration of the model. With this consideration, we have worked with the data series of (2010-2014) for validation and (2014-2016) for calibration (Fig. 5). 


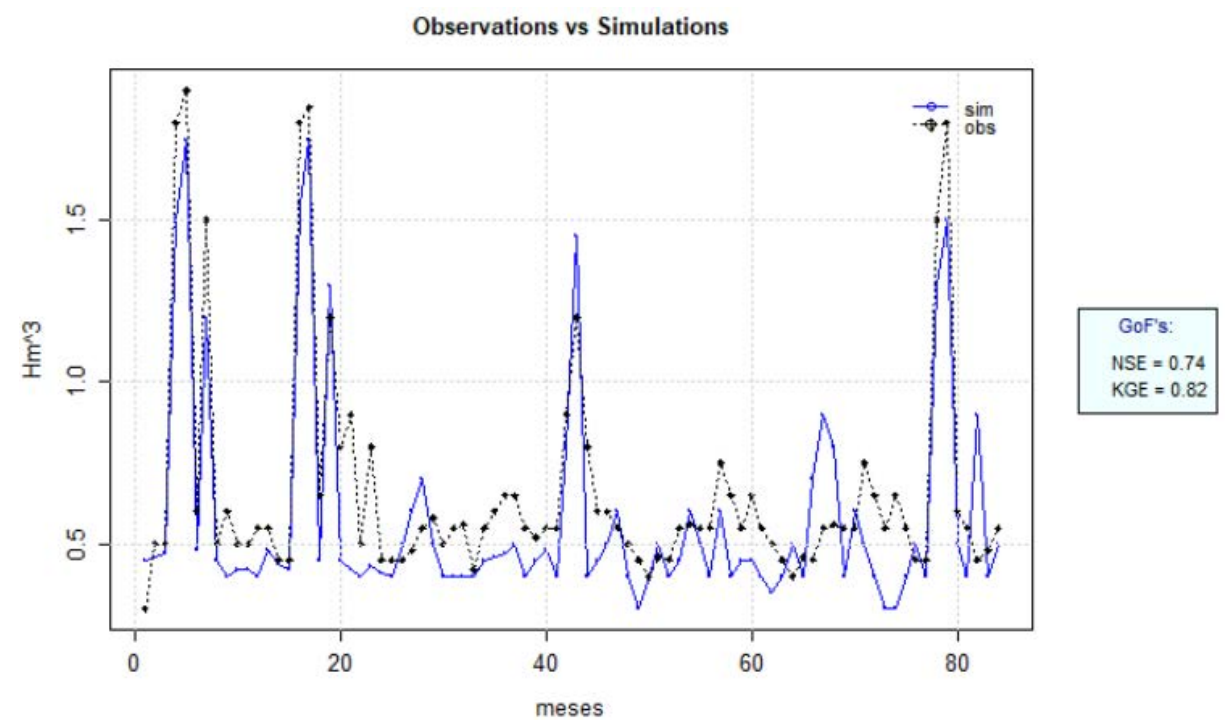

Figure 5: Comparison of contrasted values and simulated for the calibration and validation of the model.

The indicators for statistical and graphical goodness-of-fit measures between observed and simulated values show relatively high relations between the data, it has been used The Nash-Sutcliffe efficiency (NSE), with a value of 0.74 and the Kling-Gupta Efficiency (KGE) that provide a diagnostically interesting decomposition of the Nash-Sutcliffe efficiency which facilitates the analysis of the relative importance of its different components (correlation, bias and variability) in the context of hydrological modelling [12], the value of the KGE is 0.82 ; this indicates an adequate behavior of the observed and modeled data since it has taken into account phenomena such as extreme events within the analysis basin.

According to the statistical indicators [13], they could be classified within a category of "Very Good," which gives us the certainty to raise future scenarios with confidence in the results obtained.

\subsection{Analysis of scenarios}

The possible management alternatives to the system were studied to determine the optimal strategy that could be implemented with the lowest social, economic and environmental impact. In this study, four scenarios were analyzed (Table 1), in the first one there is a population growth according to the National Institute of Statistics and Census of Ecuador, in this scenario it is explained how the system behaves without any intervention, assuming that there is no variation in the water quality and quantity of the system, this analysis gives the baseline to raise scenarios of improvement to the system. In the second scenario, the creation of an operation reservoir for the supply to the population that allows diminishing the supply failures. In the third scenario, the data of agricultural demand vary, considering the months of highest rainfall as months in which the demand for the resource falls, since this is not considered within the allocation for irrigation and results in an unnecessary loss of the resource and the fourth scenario a combining the above strategies so they are compatible with each other. Finally, the advantages and disadvantages of each action strategy were analyzed. 
Table 1: Summary of the scenario's simulations.

\begin{tabular}{|c|c|c|c|}
\hline \multirow{2}{*}{ Scenarios } & \multicolumn{3}{|c|}{ Analysis } \\
\hline & Definition & Advantages & Disadvantages \\
\hline $\begin{array}{l}\text { S1: Growth } \\
\text { population }\end{array}$ & $\begin{array}{l}\text { Growth of the } \\
\text { population of the } \\
\text { Azogues city and } \\
\text { therefore more } \\
\text { significant need for } \\
\text { water resources }\end{array}$ & $\begin{array}{l}\text { Allows the analysis } \\
\text { of a near future } \\
\text { within the main } \\
\text { demand in the basin }\end{array}$ & $\begin{array}{l}\text { Does not consider } \\
\text { other demands } \\
\text { as irrigation }\end{array}$ \\
\hline $\begin{array}{l}\text { S2: Virtual } \\
\text { reservoir }\end{array}$ & $\begin{array}{l}\text { Implementation of a } \\
\text { reservoir to be able } \\
\text { to perform } \\
\text { operating rules for } \\
\text { the optimization of } \\
\text { the resource in the } \\
\text { basin analyzed }\end{array}$ & $\begin{array}{l}\text { Reduce the failures } \\
\text { in the endowments } \\
\text { for the demands in } \\
\text { the basin, allow that } \\
\text { they can raise } \\
\text { management rules } \\
\text { for the water } \\
\text { resource according } \\
\text { to the demands and } \\
\text { the importance of } \\
\text { each of them }\end{array}$ & $\begin{array}{l}\text { The reservoir is } \\
\text { considered without } \\
\text { economic and } \\
\text { social restrictions, } \\
\text { returning a } \\
\text { virtual analysis }\end{array}$ \\
\hline $\begin{array}{l}\text { S3: Decrease in } \\
\text { irrigation flows }\end{array}$ & $\begin{array}{l}\text { Optimization of the } \\
\text { water used for } \\
\text { irrigation through } \\
\text { the analysis of the } \\
\text { times of the year } \\
\text { when there is more } \\
\text { significant rainfall }\end{array}$ & $\begin{array}{l}\text { It reduces water } \\
\text { consumption due to } \\
\text { the demand for } \\
\text { irrigation, which } \\
\text { makes it possible to } \\
\text { have available } \\
\text { resources for the } \\
\text { endowment and to } \\
\text { minimize the } \\
\text { failures in the two } \\
\text { demands }\end{array}$ & $\begin{array}{l}\text { Analysis that lacks } \\
\text { complete reliability } \\
\text { because there is no } \\
\text { concrete data on the } \\
\text { need for water from } \\
\text { crops }\end{array}$ \\
\hline $\begin{array}{l}\text { S4: Combination } \\
\text { of previous } \\
\text { strategies }\end{array}$ & $\begin{array}{l}\text { Combination of } \\
\text { possible scenarios. } \\
\text { S1 }+ \text { s2 }+ \text { s3. All } \\
\text { scenarios are } \\
\text { compatible }\end{array}$ & $\begin{array}{l}\text { All scenarios are } \\
\text { compatible between } \\
\text { them and allow a } \\
\text { comprehensive } \\
\text { analysis of the area. } \\
\text { The previous scenes } \\
\text { have a high } \\
\text { possibility of being } \\
\text { fulfilled since it } \\
\text { depends on the } \\
\text { growth of the } \\
\text { population of } \\
\text { adequate } \\
\text { management of } \\
\text { the basin }\end{array}$ & $\begin{array}{l}\text { Social and } \\
\text { economic cost of } \\
\text { users who have } \\
\text { their own wells and } \\
\text { manage them in a } \\
\text { particular way }\end{array}$ \\
\hline
\end{tabular}


When projecting the population it is feasible that there are failures, because the hydrographic basin contributions do not increase and demand is made, this provides an imbalance in the management of the basin, as the population increases, either due to natural causes or migrations, demand for consumption is higher, leading to problems of scarcity [14] and this risk increases with inadequate management of the basin.

The reservoirs represent with certainty a first category water reserve [15] for the planning of the water resource if in basin problems for the fulfillment of the demands are identified, planning a reservoir is possibly the best alternative. But, before deciding on the construction, it is vital to analyze the magnitude of its advantages through the application of simulations that indicate how the presence of this structure in water management will improve. The simulation of the reservoir is the best alternative to quantify the advantages according to the economic and social cost that this represents [16]. In this investigation, none of the limitations are considered, and the scenarios are analyzed having an ideal volume for the supply to the system. Another of the topics of high interest analyzed is an optimization of the water that is used for irrigation. In water systems, more than $60 \%$ of the resource is allocated to this demand [17], and most of the time there is inadequate consumption of distribution, efficiency problems are usually the most recurrent. In the basin, there are declared monthly values for irrigation demand without considering hydroclimatic variations or the need for water in the crops.

\section{DISCUSSION}

For the first simulation scenario, the projection of population growth can be made, there are faults in the endowment, the contributions of the hydrographic basin do not increase and the demand, the response proportionally with the growth of the population, the results are presented in Table 2 .

Table 2: Results of the simulation for the consumption demand of the Azogues city in 2030.

\begin{tabular}{|c|c|c|c|c|c|c|c|}
\hline \multirow{2}{*}{ Demand } & \multirow{2}{*}{$\begin{array}{l}\text { Monthly } \\
\text { failures }\end{array}$} & \multirow{2}{*}{$\begin{array}{c}\text { Monthly } \\
\text { guarantee } \\
\text { G }\end{array}$} & \multirow{2}{*}{$\begin{array}{c}\text { Maximum } \\
\text { Monthly } \\
\text { deficit } \\
(\mathrm{Hm} 3)\end{array}$} & \multirow{2}{*}{$\begin{array}{l}\text { Maximum } \\
\text { deficit } \\
\text { two } \\
\text { months } \\
\text { (Hm3) }\end{array}$} & \multicolumn{3}{|c|}{$\begin{array}{l}\text { UTAH-DWR } \\
\text { criterion }\end{array}$} \\
\hline & & & & & $\mathrm{D}$ & E & $\mathrm{F}$ \\
\hline $\begin{array}{l}\text { Azogues } \\
\text { supply }\end{array}$ & 12 & 91.67 & 0.25 & 0.25 & $6.05 \%$ & $7.73 \%$ & $16.3 \%$ \\
\hline
\end{tabular}

According to the UTAH criterion, it is considered that there are failures when one of the following circumstances occurs: the cumulative deficit in one year exceeds the $\mathrm{D} \%$ of the demand, the deficit in two consecutive years exceeds the $\mathrm{E} \%$ of the demand and the deficit in $10 \%$. consecutive years exceeds $\mathrm{F} \%$ of demand [18]. There are six monthly failures for the demand for human demand, through the monthly guarantee formula we obtain a value of $91.67 \%$, in breach of the $95 \%$ guarantee. The maximum monthly deficit and the maximum consecutive deficit in two months was $0.25 \mathrm{Hm} 3$. According to the criterion UTAH-DWR the assurance of the demand meets for the first two years, while for ten years does not meet the test giving values higher than those raised for domestic use $(\mathrm{D}=5, \mathrm{E}=10$ and $\mathrm{F}=16)$.

With the entrance of the reservoir with the ideal economic and social conditions we can see (Fig. 6) that there is no month with failures in the endowment, the volume of the reservoir is $0.8 \mathrm{Hm} 3$ and in the simulation it is analyzed how its capacity varies according to the water supply and in Fig. 7 are the results with the optimization of the use of water for irrigation. 


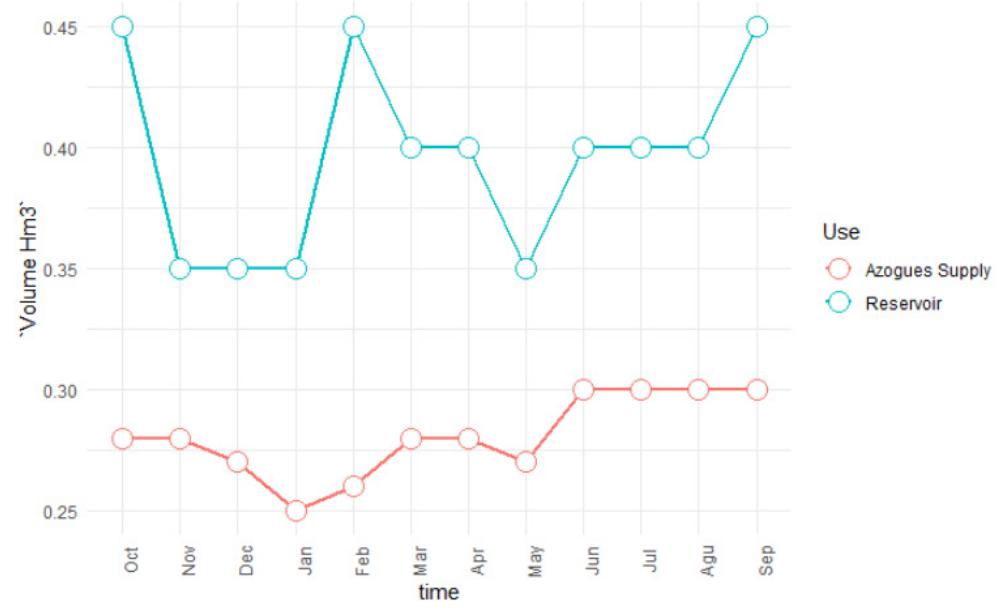

Figure 6: Endowment with the presence of a reservoir. No system failures.

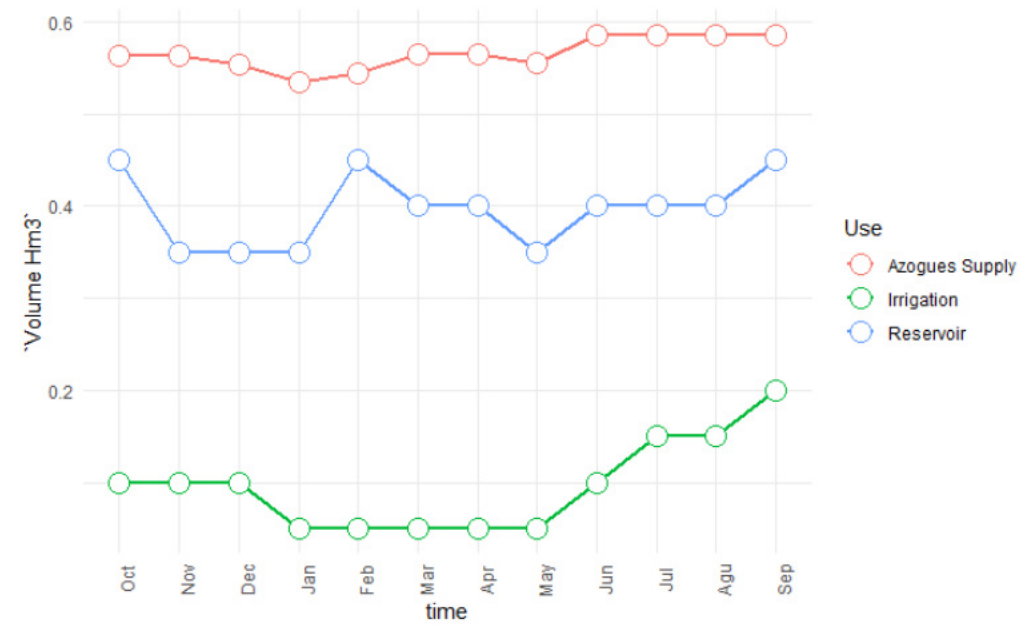

Figure 7: Presence of a reservoir and irrigation supply optimization. No system failures.

The allocation of water for irrigation decreases and a rule of operation is used in conjunction with the reservoir to manage the basin with priority of endowment for the city. Only optimizing the watering can be seen as the volume of the idea reservoir decreases to $0.5 \mathrm{Hm} 3$, which is the volume of water needed to operate the basin without problems. In Fig. 8 , the simulation is analyzed until the year 2030 with the increase of the population, the optimization of the irrigation and the presence of the virtual reservoir, decreasing the failures to 5 monthly and increasing the guaranteed rate to $97 \%$ fulfilling the criterion of warranty analyzed.

The increase in the need for water by the population is evident, but with the proposed strategy that includes the reservoir and the optimization of the irrigation system, the year 2013 is reached with few faults, within the UTAH criterion. 


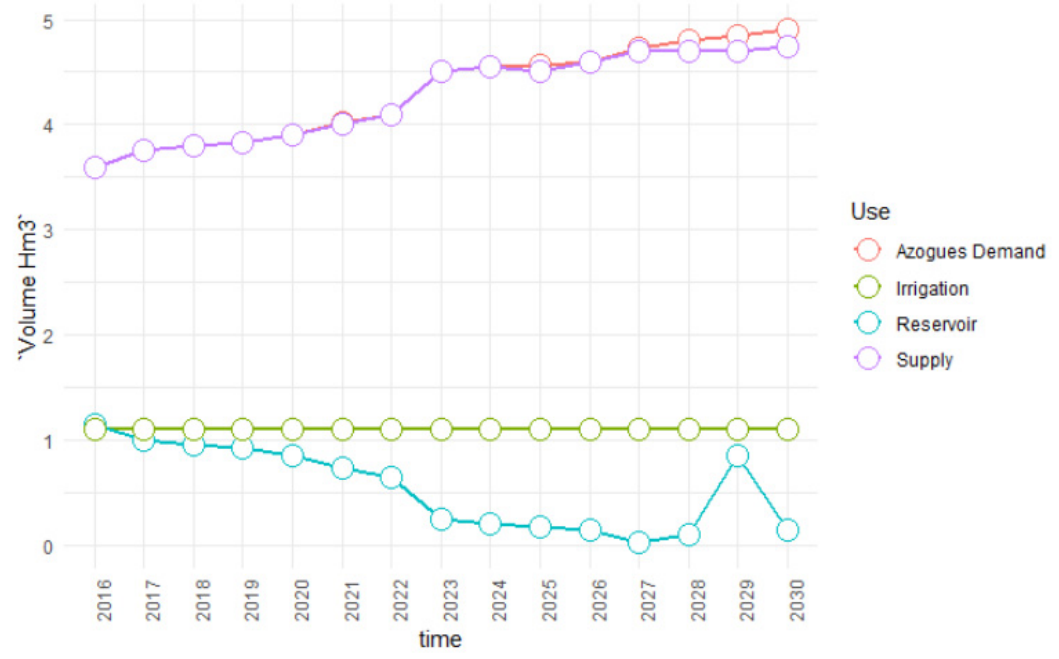

Figure 8: Simulation for 2030 year.

\section{CONCLUSIONS}

The proposed methodology is based on the use of decision support systems (AQUATOOL-SIMGES) to allow decision-makers to detect characteristics and improve aspects of a basin from the point of view of water management, the importance of the use of these methodologies allows us to understand the behavior of a basin that has undergone changes in land use of great importance and that has affected its hydrological response. In the Tabacay river basin, the amount of water is relatively low, and without proper management, it can be seen as for the present time, and the population suffers from failures in the endowment they require. With scenarios that are very likely to be met and if the same management system is followed by 2030 , the city will suffer from severe drought problems, but if action plans are applied, such as those treated in this research, this risk of running out of water can be reduced. The scenarios are proposed until the year 2030 and with the management systems this horizon is reached with the reservoir yielding at its maximum; for this reason, it is necessary to analyze other variables to the system such as water quality and variations in meteorological variables due to climate change.

\section{ACKNOWLEDGEMENTS}

The study was performed with support of the University Catholic of Cuenca, through the sixth call for research projects. Thanks to the water company of the Azogues city for the support provided in the collection of information.

\section{REFERENCES}

[1] Serrat-Capdevila, A., Valdes, J.B. \& Gupta, H., Decision support systems in water resources planning and management: Stakeholder participation and the sustainable path to science-based decision making. Efficient Decision Support Systems - Practice and Challenges From Current to Future, ed., C. Jao, InTech, p. 542, 2011.

[2] Ruiz-Ortiz, V., García-López, S., Solera A. \& Paredes, J., Contribution of decision support systems to water management improvement in basins with high evaporation in Mediterranean climates. Hydrol. Res., pp. 1-17, 2019. 
[3] Pedro-Monzonís, M., Jiménez-Fernández, P., Solera, A. \& Jiménez-Gavilán, P., The use of AQUATOOL DSS applied to the System of Environmental-Economic Accounting for Water (SEEAW). J. Hydrol., 533, pp. 1-14, 2016.

[4] Ochoa-Sánchez, A., Crespo, P., Carrillo-Rojas, G., Sucozhañay, A. \& Célleri, R., Actual evapotranspiration in the High Andean grasslands: A comparison of measurement and estimation methods. Front. Earth Sci., 7(March), 2019.

[5] Pauta, G., Urgilés, P. \& Vázquez, G., Water Quality Control and Hydrogeochemistry in the Microbasin of the Tabacay River Control de Calidad del Agua $e$ Hidrogeoquímica en la Microcuenca del río Tabacay, vol. 3, pp. 277-291, 2017.

[6] Yaguache, D., Felipe, L., Zambrano, V. \& Fernando, R., Modelación de la oferta hídrica en una cuenca de montaña tropical en función de su cobertura del suelo water availability modelling for a tropical mountain catchment as a function of its soil cover. Aqua-LAC, 7, pp. 63-76, 2015. (In Spanish.)

[7] Momblanch, A., Paredes-arquiola, J., Andreu, J. \& Hernández, J.G., Análisis de medidas para la mejora de la calidad del agua en el tramo bajo del río Lurín (Perú). IV Jornadas Ing. del Agua, October, 2015. (In Spanish.)

[8] Pedro-Monzonís, M., Solera, A., Ferrer, J., Andreu, J. \& Estrela, T., Water accounting for stressed river basins based on water resources management models. Sci. Total Environ., 565, pp. 181-190, 2016.

[9] Andreu Alvarez, J., Solera, A., Capilla Roma, J. \& Ferrer Polo, J., Modelo SIMGES de simulación y Gestión de los Recursos Hídricos, incluyendo utilización conjunta. Univ. Politécnica Val., p. 102, 2017. (In Spanish.)

[10] Avilés, A. \& Solera, A., Estimación del riesgo de fallo en el suministro de agua como ayuda a la planificación y gestión de recursos hídricos. Maskana, 3(2), pp. 77-86, 2012. (In Spanish.)

[11] Paredes, J., Andreu, J. \& Solera, A., A decision support system for water quality issues in the Manzanares River (Madrid, Spain). Sci. Total Environ., 408(12), pp. 2576-2589, 2010.

[12] Zambrano-Bigiarini, M., R Package hydroGOF, 2017.

[13] Fatichi, S., Rimkus, S., Burlando, P., Bordoy, R. \& Molnar, P., Elevational dependence of climate change impacts on water resources in an Alpine catchment. Hydrol. Earth Syst. Sci. Discuss., 10(3), pp. 3743-3794, 2013.

[14] Padrón, A. \& Cantú, P., El Recurso Agua En El Entorno De Las Ciudades Sustentables. Culcyt, Univ. Autónoma Ciudad Juárez, 31(6), pp. 15-25, 2009. (In Spanish.)

[15] Rodríguez Perea, A. \& Gelabert Ferrer, B., La gestión integrada de los recursos hídricos en las Islas Baleares. Investig. Geográficas, 41(41), pp. 49-64, 2015. (In Spanish.)

[16] Torres-Bejarano, F., Coba, J., Cuevas, C., León, H., Rodriguez Cuevas, Rodelo, R., La modelación hidrodinámica para la ges...o, Colombia _Elsevier Enhanced Reader.pdf. Rev. Int. Métodos Numéricos para Cálculo y Diseño en Ing., 32(3), pp. 163-172, 2015. (In Spanish.)

[17] CEPAL, Diagnóstico de la estadísticas del agua en Ecuador. Diagnostico la Inf. Estad. del agua, p. 81, 2013. (In Spanish.)

[18] Diputación Provincial de Alicante, Desarrollo Sostenible, Uso Conjunto Y Gestion Integral de Recursos Hidricos. Dirección del ciclo Hídirico, 2010. (In Spanish.) 